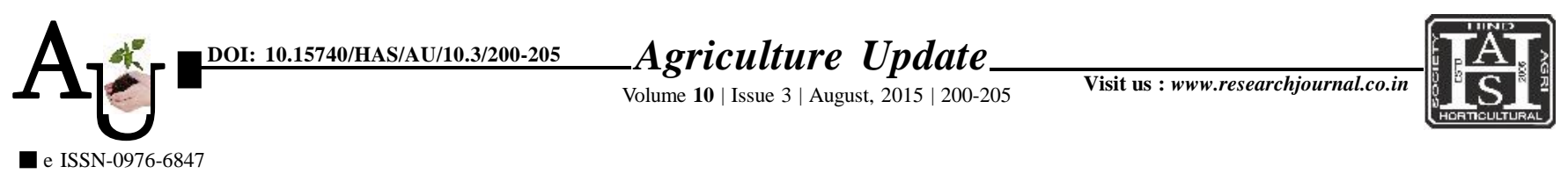

\title{
Research Article: Self-help groups : A tool of rural women economic upgradation
}

DEEMA CHAWLA AND CHANDER BHAN

Article Chronicle : Received :

24.04.2015;

Revised :

04.07.2015;

Accepted :

05.08.2015

Key Words:

Economic

upgradation, Rural women, Self-help groups

Author for correspondence :

\section{SEEMA CHAWLA}

Krishi Vigyan Kendra

(S.K.R.A.U.),

SRIGANGANAGAR

(RAJASTHAN) INDIA

Email: seema_jasuja@

yahoo.com

See end of the article for

authors' affiliations
SUMMARY : In recent years self-help groups have become significant institutions for rural development. It is now being increasingly realized that instead of targeting the individuals in the process of development, it would be more useful to adopt the approach make available the collective wisdom and combined resources for any task. Though SHGs have gained access to all government officials, they have not become bold enough to speak out as demonstrated at some forums in the country. The present study carried out in Sriganganagar district of Rajasthan state during 2013-2014, revealed that members of the rural women's SHGs have been benefited in many ways such as exposure to different development programmes of the Government, exposure to the banks as well as transactions, their confidence level has been increased because of their own savings and easy access to loan from SHG. There was a good impact on economic aspects of the members in their financial position, family income and improvement in the employment generation through different income generation activities. Major reasons for group formation by the rural women were to take advantage of group action ( $85 \%$ ), followed by improved employment activities $(79.17 \%)$, meeting for collective decisions (75\%), overcoming exploitation of money lenders (75\%), internal lending (66.67\%), improved social participation (66.67\%), saving money regularly (62.50\%) and general income (54.17\%). The social impacts of SHGs on rural women were exposure to different development departments and participations in meetings, decision making and exposure to banks as well as to transactions. The most influential change was observed in loan borrowing pattern of the SHG members as most of them had developed their own funds, were able to transact with the banks and the borrowing of loans from the money lenders had reduced to considerable extent. The major impacts like improvement in the economic status of the family (80.83\%),avoiding exploitation by money lenders (77.33\%), easy to get money in emergency situation and facilitates savings (73.33\%) have been witnessed for the empowerment of women. The reduced rate of bank interest, simple procedure to be followed for releasing the loan, marketing and transport facilities to be improved, training on skill improvement, increase in the duration of the training, enhanced repayment period were the other suggestions highlighted the strengthening of rural women SHGs in order to provide more opportunity for empowerment of farm women.

How to cite this article : Chawla, Seema and Bhan, Chander (2015). Self-help groups : A tool of rural women economic upgradation. Agric. Update, 10(3): 200-205. 